\title{
海洋環境下におけるステンレス鉄筋の耐食性に 関する研究
}

\author{
山路 徹 $^{1}$ - 濱田秀則 $2 \cdot$ 水間誠治 $3 \cdot$ 山本俊彦 4 \\ 1正会員 関西国際空港(株)建設事務所(前(独)港湾空港技術研究所) ( $\bar{T} 549-0001$ 泉佐野市泉州空港北1) \\ E-mail: yamaji_t@kald.co.jp \\ 2正会員 九州大学大学院(前(独)港湾空港技術研究所) ( $\bar{\top}$ 819-0395 福岡市西区元岡744) \\ E-mail: h-hamada@doc.kyushu-u.ac.jp \\ 3 正会員 大同特殊鋼(株)ステンレス鋼営業部 (广108-0075 東京都港区港南1-6-35) \\ E-mail: s-mizuma@ac.daido.co.jp \\ 4正会員 大同大学 (广457-8532 名古屋市南区白水町40) \\ E-mail: yamamoto@daido-it.ac.jp
}

\begin{abstract}
海洋環境下に位置する港湾RC構造物への適用を目標とし，3種類のステンレス鉄筋(SUS430, SUS304, SUS316)の而食性に関して，コンクリート模擬溶液浸漬試験および海洋環境暴露試験による検討を行った. その結果, 各ステンレス鉄筋における腐食発生限界塩化物イオン濃度は普通鉄筋と比べて極めて大きく, 少なくとも $12 \mathrm{~kg} / \mathrm{m}^{3}$ 程度以上であると推測された。また，普通鉄筋の場合と比べて，鋼材の腐食に対する ひび割れ幅の限界值を緩和できることが確認された。上記の結果を基に港湾 $\mathrm{RC}$ 構造物のライフサイクル コストを試算した結果，ステンレス鉄筋を用いた方が，普通鉄筋を用い供用期間中に補修を行う場合より 安くなる可能性が示された。
\end{abstract}

Key Words : port RC structure, stainless steel, chloride ion concentration, steel corrosion, crack

\section{1. はじめに}

代表的な港湾コンクリート構造物である栈橋上部工は 海面近傍に位置していることから，塩化物イオンが多量 に供給され，かつ腐食反応に必要な酸素も十分に供給さ れるため, 非常に厳しい塩害環境にある.このような特 に厳しい塩害環境においては，耐食性に優れるエポキシ 樹脂塗装鉄筋やステンレス鉄筋などを用いた方が得策で あると考える．なお，エポキシ樹脂塗装鉄筋はステンレ ス鉄筋に比べて安価である。しかし，エポキシ樹脂塗装 鉄筋の場合，普通鉄筋の周囲のみをエポキシ樹脂で覆つ ているため，運搬中あるいは施工中においてエポキシ樹 脂被覆部が損傷する可能性があり，場合によってはコン クリート打設前にエポキシ樹脂被覆部に対して補修が必 要となる．一方，ステンレス鉄筋の場合は，鋼材そのも のの耐食性が優れているため，運搬中あるいは施工中に おいて普通鉄筋と同様に扱うことができる.

ステンレス鉄筋の使用時においても，通常の鉄筋の場 合同様に鉄筋腐食照查を行い，設計耐用期間中に鋼材腐 食によって構造物が所要の性能を損なわないことを確認 する必要がある．この照査の際，ステンレス鉄筋の腐食

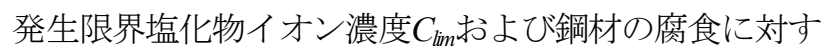
るひび割れ幅の限界值 $w_{a}$ を適切に設定することが重要で ある.

ステンレス鉄筋の $C_{\text {lin }}$ に関する研究は，海外において は比較的研究事例 ${ }^{1,2)}$ も多い. Pedeferriらはコンクリート 中の細孔溶液を模擬した溶液（以下，模擬溶液）を用い て電気化学的手法に基づく評価を行っており，一般的な ステンレス鋼であるSUS304の場合で， $C_{\text {lin }}=4(\%$ : セメ ント質量比)程度と報告している（単位セメント量を300 $\mathrm{kg} / \mathrm{m}^{3}$ とすると $300 \times 4 \%=12 \mathrm{~kg} / \mathrm{m}^{3}$ に換算 $)^{2}$. 一一方，国内で は研究事例は少ない，その中で，太らはコンクリートを 練り混ぜる際に塩化物イオンを混入させた試験体におい て, SUS304の場合で24 kg/m混入させても腐食が見られ なかったと報告している゙．これらの研究の多くは，練 混ぜ時に多量の塩化物イオンを混入させた場合や，模擬 溶液やコンクリート試験体を用いて電気化学的手法によ り評価した場合のものであり, 実際の環境に対応する, 塩化物イオンを外部から侵入させた場合についての検討 は少ない.

一方，ステンレス鉄筋の $w_{a}$ に関する研究については, $C_{\text {lin }}$ の場合に比べて検討事例が非常に少ない. 
表-1ステンレス鋼の組成の一例

\begin{tabular}{|c|c|c|c|c|c|}
\hline \multirow{2}{*}{ 鋼種名称 } & \multirow{2}{*}{$\begin{array}{c}\text { ステンレス鋼 } \\
\text { 種類 }\end{array}$} & \multicolumn{3}{|c|}{ 成分 (質量\%) } & 耐孔食性 \\
\cline { 3 - 6 } & & $\mathrm{Ni}$ & $\mathrm{Cr}$ & $\mathrm{Mo}$ & 指標 $^{*}$ \\
\hline SD295(炭素鋼) & & - & - & - & - \\
\hline SUS430 & \multirow{2}{*}{ フェライト系 } & - & 16.3 & - & 16.3 \\
\hline SUS304 & \multirow{2}{*}{ オーステナイト系 } & 8.1 & 18.7 & - & 18.7 \\
\cline { 4 - 6 } & 10.1 & 16.8 & 2.0 & 23.9 \\
\hline SUS316 & & \multicolumn{5}{|c}{$*=\mathrm{Cr}+3.5 \mathrm{M} 0+16 \mathrm{~N}(\%)$} \\
\hline
\end{tabular}

表-2 ステンレス鋼の力学的特性

\begin{tabular}{|c|c|c|c|c|c|}
\hline 鋼種 & $\begin{array}{c}\text { 引張強度 } \\
\left(\mathrm{N} / \mathrm{mm}^{2}\right)\end{array}$ & $\begin{array}{c}\text { 降伏強度 } \\
\left(\mathrm{N} / \mathrm{mm}^{2}\right)\end{array}$ & $\begin{array}{c}\text { 伸び } \\
(\%)\end{array}$ & $\begin{array}{c}\text { 弾性 } \\
\text { 係数 } \\
\left(\mathrm{kN} / \mathrm{mm}^{2}\right)\end{array}$ & $\begin{array}{c}\text { 熱膨張 } \\
\text { 係数 } \\
\left(\times 10^{-6}\right)\end{array}$ \\
\hline $\begin{array}{c}\text { 炭素鋼 } \\
(\mathrm{SD} 295)\end{array}$ & 568 & 386 & 24.3 & 204 & 11.0 \\
\hline SUS430 & 468 & $244 *$ & 30.3 & 169 & 10.4 \\
\hline SUS304 & 672 & $364 *$ & 42.7 & 162 & 16.4 \\
\hline SUS316 & 627 & $331 *$ & 43.8 & 187 & - \\
\hline \multicolumn{7}{|c|}{$* 0.2 \%$ ひずみ時 }
\end{tabular}

本研究では，まず模擬溶液による試験（模擬溶液浸漬 試験） 4)を行い，ステンレスの耐食性の把握を行った. 次に，コンクリート試験体を用いた海洋環境暴露試験

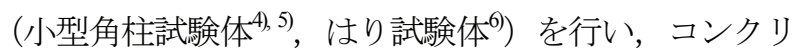
一ト外部から塩化物イオンを侵入させ, 鉄筋位置の塩化 物イオン濃度と腐食の状況を比較することにより，ステ ンレス鉄筋における $C_{\text {lin }}$ に関する検討を行った。また, 上記の暴露試験の際に，ひび割れ部での腐食性状の確認 も併せて行い，ステンレス鉄筋の $w_{a}$ に関する検討も行っ た. そして，上記の実験結果を基にステンレス鉄筋を用 いた際の鉄筋腐食照査を行い，その際のLCC（ライフサ イクルコスト）の比較を試みた。

\section{2. 使用したステンレス鉄筋の諸特性}

\section{(1) ステンレス鋼の組成}

ステンレス鋼は，炭素鋼の耐食性を向上させる目的で $10.5 \%$ 以上のCr（クロム）を含有する鋼と定義されてい る. 本試験では, SUS430, SUS304, SUS316の3種類のス テンレス鋼を用いた．ステンレス鋼の組成を表-1に示す。 CrやMo（モリブデン）等の添加量が増えると耐食性は 向上する. 表中に耐孔食性指標 $)^{\prime}(=\mathrm{Cr}+3.5 \mathrm{Mo}+16 \mathrm{~N}$, $\mathrm{N}$ : 窒素) の值を示している。この值が高いほど腐食が 生じにくい. そのため, 一般的な耐食性としては, SUS316が最も優れ, 次にSUS304, SUS430となる. なお, SUS304，SUS430に関しては，耐食性に優れるとはいっ ても，ステンレス鋼単体で海洋環境下に使用すると腐食 が生じる，そのため，海水が鋼材表面に直接接するよう な環境においては，SUS304やSUS430単体では一般的に 使用されない。

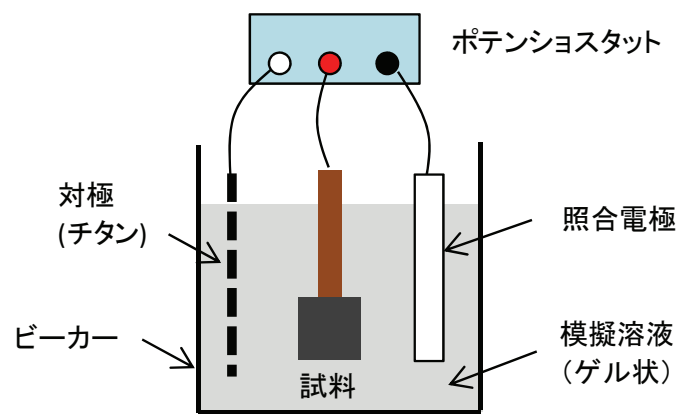

図-1 試験方法概略図

表-3 模擬溶液組成および測定項目

\begin{tabular}{|c|c|c|c|c|c|}
\hline \multirow{2}{*}{} & \multicolumn{5}{|c|}{$\mathrm{Cl}(\%$ : 質量比) } \\
\cline { 2 - 6 } & 1.9 & 5.0 & 8.3 & 12.7 \\
\hline \multirow{2}{*}{$\mathrm{pH}$} & 7.2 & $\bigcirc$ & $\bigcirc$ & $\bigcirc$ & $\bigcirc$ \\
\cline { 2 - 6 } & 12.5 & $\bigcirc$ & $\bigcirc$ & $\bigcirc$ & $\bigcirc$ \\
\hline \multicolumn{5}{|c|}{ O:アノード分極, ○:アノード分極+自然電位変化 }
\end{tabular}

\section{(2) 力学的特性}

力学的特性を表-2に示す. SUS304, SUS316において は，伸びが大きいことを除いて，炭素鋼とほぼ同等の性 質を有している.

\section{3. 模擬溶液浸漬試験}

\section{(1) 試験概要}

アルカリ環境下および中性環境下における腐食性状を 把握するため, コンクリート細孔溶液の模擬溶液中にお いてアノード分極試験および自然電位の測定を行った

\section{a) 試料}

試験に用いた鋼種は表-1に示したSUS430，SUS304, およびSUS316の 3 種類である. 試料形状は $20 \times 20 \times 2 \mathrm{~mm}$ （図-1参照）であり，試験前に試料表面を脱脂・洗浄し たのみで研磨は実施していない.

\section{b) 試験方法}

試験に用いた模擬溶液の組成と測定項目の一覧を表-3

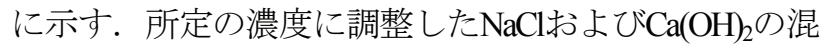
合溶液に吸水性高分子を添加し，ゲル状にしたものを模 擬溶液とし，この模擬溶液に試料を挿入して試験を実施 した ${ }^{8}$ ．なお，模擬溶液のCl濃度は $1.9 ， 5.0 ， 8.3 ， 12.7 \%$

（質量比）の4水準である．また， $\mathrm{Ca}(\mathrm{OH})_{2}$ を無添加の場 合 $(\mathrm{pH}=7.2)$ は中性化したコンクリート中あるいはひび割 れ箇所近傍を, $\mathrm{Ca}(\mathrm{OH})_{2}$ を添加した場合 $(\mathrm{pH}=12.5)$ は健全 なコンクリート中を想定したものである.

アノード分極試験の概略図を図-1に示す，照合電極に 飽和 $\mathrm{KCl}-\mathrm{Ag} / \mathrm{AgCl}$ 電極（以下, SSE），対極にチタンを用 い, $20 \mathrm{mV} / \mathrm{min}$.の走查速度でアノード方向へ分極し， 100 $\mu \mathrm{A} / \mathrm{cm}^{2}$ の電流が流れた電位を測定した。この電位は，鋼 材の耐食性の指標となる孔食発生電位として定義される 
ものである.

自然電位測定では，模擬溶液中に試料および照合電極 （SSE）を挿入し，約10日間連続で計測を行った．試験 方法は図一から対極を除いたものと同様である。その後, 腐食の有無を確認した。 なお, 模擬溶液のC濃度は8.3, $12.7 \%$ の水準, $\mathrm{pH}$ H7.2と12.5の2水準である.

\section{(2) 試験結果}

\section{a) アノード分極特性および孔食発生電位}

図-2にCl濃度 $12.7 \% ， \mathrm{pH}=12.5$ の時のアノード分極曲線 を示す．各鋼種の差が明確であり, SUS430, SUS 304, SUS316の順に孔食発生電位が貴であることが分かる. 図-2から得られる孔食発生電位とCl濃度の関係を図-3に 示す．C濃度が高いほど孔食発生電位は卑になっており， また, $\mathrm{Ca}(\mathrm{OH})_{2}$ を添加した場合 $(\mathrm{pH}=12.5)$ の方が貴になっ ている.

\section{b) 自然電位変化と腐食の関係}

図-4に模擬豁液中における各ステンレス鋼の自然電位 の経時変化を示す。浸漬後の自然電位が孔食発生電位付 近もしくはそれより貴な電位を示した場合にのみ腐食が 生じた. SUS316は，全ての試験において腐食は観察さ れず，SUS304はC濃度 $12.7 \%$ pH=7.2の場合にのみ腐食 が観察された．SUS430については， $\mathrm{pH}=12.5$ の模擬溶液 中では腐食が観察されなかったが, $\mathrm{pH}=7.2 の$ 場合ではCl 濃度 8.3 \%および $12.7 \%$ \%のずれの場合にも腐食が観察さ れた。

以上の結果から, $\mathrm{pH}=12.5$ の場合には, SUS316, SUS304，SUS430において腐食が開始するCl濃度はいず れも 12.7 \%以上であり, $\mathrm{pH}=7.2$ の場合にはSUS316では 12.7 \%以上，SUS304では8.3〜 $12.7 \%$ の範囲内，SUS430で は $8.3 \%$ より低濃度であると推測される.

\section{c) コンクリート中の濃度への換算}

模擬溶液中のCl濃度から，コンクリート中における塩 化物イオン濃度を下記の方法で換算する. なお，換算方 法には確立されたものが無いため，ある一例として文献 9）で示された手法に基づき算定を行った.

i)細孔溶液量の算定

コンクリート中の体積あたりの細孔溶液量 $p(\%$ : 容積 比)は, 水量 $W\left(\mathrm{~kg} / \mathrm{m}^{3}\right)$, セメント量 $C\left(\mathrm{~kg} / \mathrm{m}^{3}\right)$ およびセメン 卜の水和率 $h(\%)$ から式(1)で算定される.

$$
p=\frac{W-C \times h / 100}{1000} \times 100
$$

ここで，セメントの水和率 $h=20 \%$ とした. $W=150 \mathrm{~kg} / \mathrm{m}^{3}$, $C=300 \mathrm{~kg} / \mathrm{m}^{3}(\mathrm{~W} / \mathrm{C}=0.50)$ として $p$ を計算すると， $9.0 \%$ と算 定された.

ii) 自由塩化物イオン濃度の算定

コンクリート中の自由塩化物イオン濃度 $C_{v}\left(\mathrm{~kg} / \mathrm{m}^{3}\right)$ は, 体積あたりの細孔溶液量 $p(\%$ : 容積比)および模擬溶液
中のCl濃度 $a(\%$ : 質量比)から式(2)で算定される.

$$
C_{v}=1000 \times \frac{a}{100-a} \times \frac{p}{100}
$$

iii) 固定化塩素濃度の算定

固定化塩素濃度 $a_{f x}(\%$ : セメント質量比)は, 石田らの 研究10)で得られた塩化物イオン量と固定化塩素量の関係 を二直線に近似した式(3)で算定した.

$$
\begin{aligned}
& a_{m o b}<0.358 \text { のき } a_{f i x}=4.74 \times a_{m o b} \\
& a_{m o b} \geq 0.358 \text { とき } \quad a_{f i x}=0.240 \times a_{m o b}+1.615
\end{aligned}
$$

ここで, $a_{m o b}(\%$ : セメント質量比 $)$ は, 模擬溶液中の塩物 イオン濃度をセメント質量比に換算したものであり, 下 式で計算される.

$$
a_{m o b}=a \times \frac{W}{C}
$$

iv) 固定化塩化物イオン濃度の算定

コンクリート中における固定化塩化物イオン濃度 $C_{f x}$ $\left(\mathrm{kg} / \mathrm{m}^{3}\right)$ は, 固定化塩素濃度 $a_{f \mathrm{f}}$ およびセメント量 $C$ から式

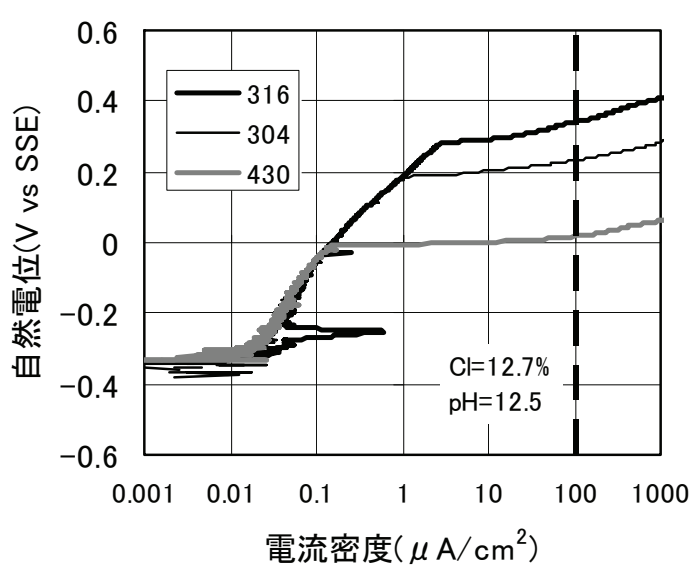

図-2 アノード分極曲線

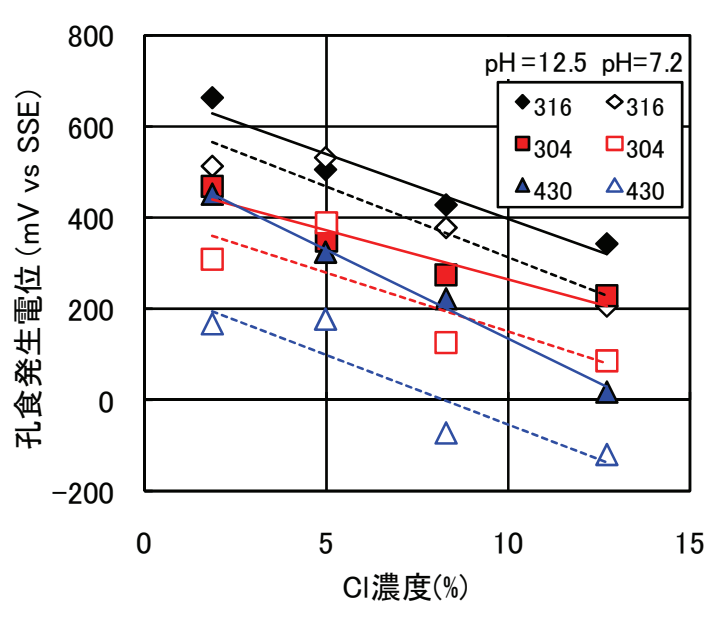

図-3Ｃ：濃度と孔食発生電位の関係

(実線 : $\mathrm{pH}=12.6$ の回帰直線, 点線 : $\mathrm{pH}=7.2$ の回帰直線) 

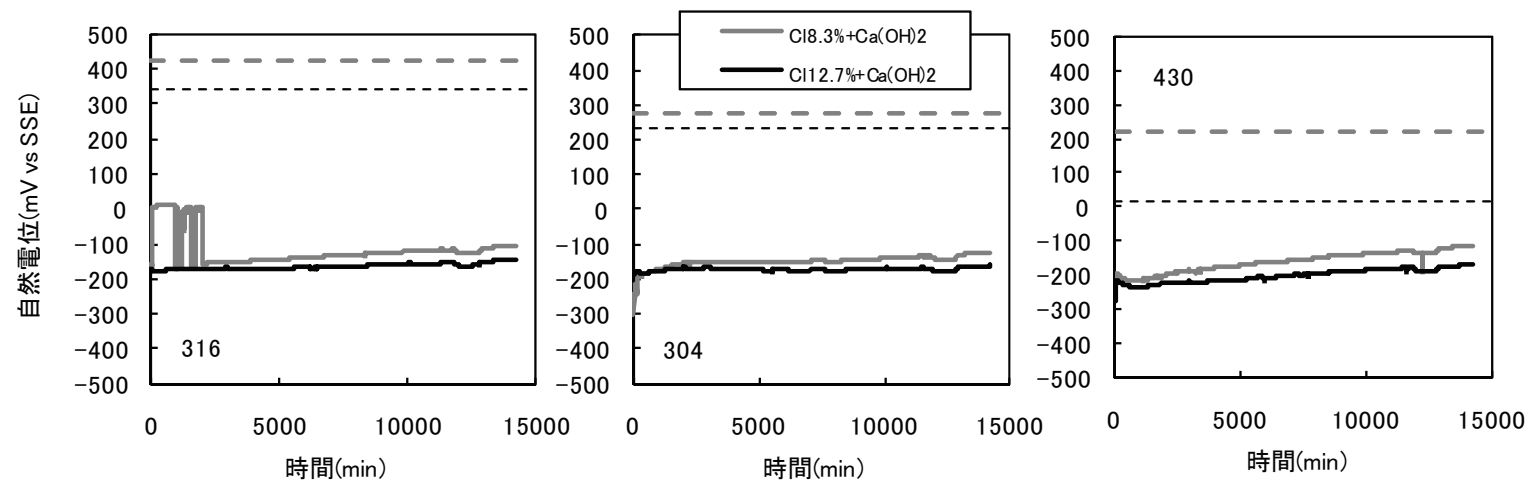

$\left(\mathrm{pH}=12.5: \mathrm{Ca}(\mathrm{OH})_{2}\right.$ 添加 $)$
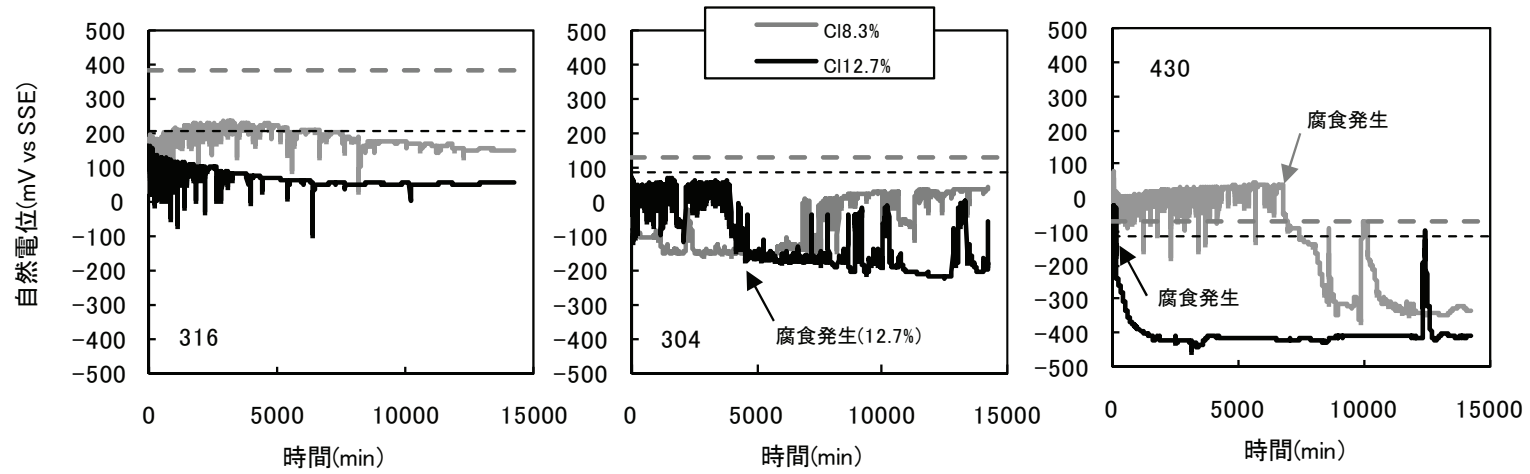

$\left(\mathrm{pH}=7.2: \mathrm{Ca}(\mathrm{OH})_{2}\right.$ 無添加 $)$

図-4 各ステンレス鋼の自然電位変化（実線 : 自然電位，横点線 : 孔食発生電位)

表-4 コンクリート中への濃度への換算結果

\begin{tabular}{|r|r|r|r|r|r|}
\hline$a(\%)$ & $\begin{array}{c}\mathrm{C}_{\mathrm{v}} \\
\left(\mathrm{kg} / \mathrm{m}^{3}\right)\end{array}$ & $\mathrm{a}_{\mathrm{mob}}(\%)$ & $\mathrm{a}_{\mathrm{fix}}(\%)$ & $\begin{array}{c}\mathrm{C}_{\mathrm{fix}} \\
\left(\mathrm{kg} / \mathrm{m}^{3}\right)\end{array}$ & $\begin{array}{c}\mathrm{C}_{\text {tot }} \\
\left(\mathrm{kg} / \mathrm{m}^{3}\right)\end{array}$ \\
\hline 12.7 & 13.1 & 6.4 & 3.1 & 9.4 & 22.5 \\
\hline 8.3 & 8.1 & 4.2 & 2.6 & 7.8 & 16.0 \\
\hline 5.0 & 4.7 & 2.5 & 2.2 & 6.6 & 11.4 \\
\hline 3.0 & 2.8 & 1.5 & 2.0 & 5.9 & 8.8 \\
\hline
\end{tabular}

(5)で算定される.

$$
C_{f i x}=C \times \frac{a_{f i x}}{100}
$$

v) 全塩化物イオン濃度の算定

全塩化物イオン濃度は自由塩化物イオン濃度と固定化 塩化物イオン濃度の和となる. そのため, コンクリート 中の全塩化物イオン濃度 $C_{\text {tot }}\left(\mathrm{kg} / \mathrm{m}^{3}\right)$ は式(6)で求められる.

$$
C_{t o t}=C_{v}+C_{f i x}
$$

上記のようにして求めたコンクリート中の塩化物イオン 濃度の值を表-4に示す。模擬溶液の試験結果でCl濃度 $a=12.7 \%$ の場合は $22.5 \mathrm{~kg} / \mathrm{m}^{3}$ の值となった. 各ステンレス 鋼は $12.7 \%$ で腐食が生じていなかったため, コンクリー 卜中における腐食発生限界濃度は20 kg/m 程度以上であ る可能性がある. なお，コンクリート中に塩化物イオン
を混入させた文献3)の試験結果においても，SUS304は $20 \mathrm{~kg} / \mathrm{m}^{3}$ 以上でも腐食が生じていない.

以上より，ステンレス鉄筋がアルカリ環境下で高い耐 食性を有すること，また鋼種による差があることが確認 された. 4.ではコンクリート外部から塩化物イオンを侵 入させることにより, 高塩化物イオン濃度環境下でのス テンレス鉄筋の腐食の有無を確認し，実環境下における 腐食発生限界塩化物イオン濃度 $C_{\text {lim }}$ について検討を行う。

\section{4. 海洋環境暴露試験}

\section{(1) 実験概要}

実際の海洋環境下と同様に，コンクリート外部から塩 化物イオンが浸透する場合を想定し，自然海水の散布が 1日2回（1回約3時間）繰り返される屋外環境に，鉄筋を 埋設した小型角柱試験体を5.7年，はり試験体を5.1年間 暴露した. 暴露後, 鉄筋の腐食状況および鉄筋位置の塩 化物イオン濃度などの各種調査を実施した。

\section{a) 試験体}

i)小型角柱試験体，ii)はり試験体，の2種類を用いた.

i) 小型角柱試験体

試験体形状を図-5に，試験体配合を表-5に示す，使用 


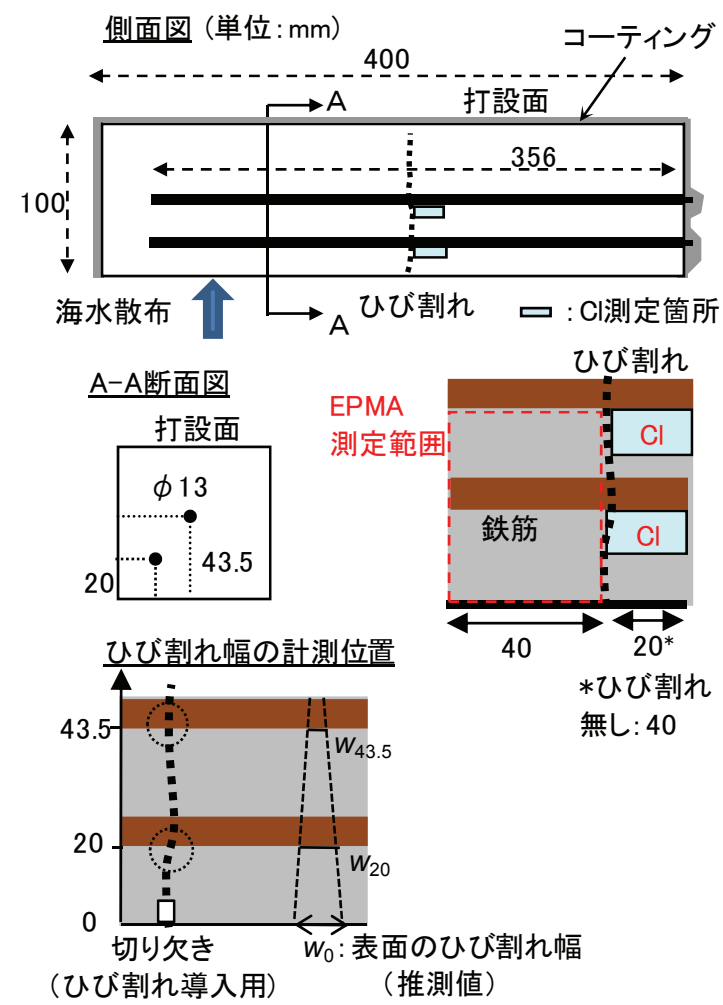

図-5 小型角柱試験体形状

表-5 コンクリート配合

\begin{tabular}{|c|c|c|c|c|c|}
\hline \multirow{2}{*}{ 種類 } & \multirow{2}{*}{ W/C } & \multicolumn{4}{|c|}{ 単位量 $\left(\mathrm{kg} / \mathrm{m}^{3}\right)$} \\
\cline { 3 - 6 } & & $\mathrm{W}$ & $\mathrm{C}$ & $\mathrm{S}$ & $\mathrm{G}$ \\
\hline 小型 & 0.60 & 159 & 265 & 814 & 1036 \\
\hline はり & 0.61 & 178 & 292 & 832 & 987 \\
\hline
\end{tabular}

したセメントは普通ポルトランドセメント, 細骨材は静 岡県小笠産山砂（密度 $2.61 \mathrm{~g} / \mathrm{cm}^{3}$, 粗粒率 2.65 ), 粗骨材 は茨城県岩瀬産砕石（最大粒径 $20 \mathrm{~mm}$, 密度 $2.64 \mathrm{~g} / \mathrm{cm}^{3}$, 粗粒率6.71），練混ぜ水は水道水である。用いた鋼種は 表-1に示した普通鉄筋（炭素鋼），SUS430，SUS304お よびSUS316の4種類である。試験体は100×100×400 mm の角柱であり， $\phi 13 \mathrm{~mm}$ (長さ356mm)の丸鋼がかぶり20, $43.5 \mathrm{~mm}$ の箇所に埋設されている. なお，丸鋼のステン レス鉄筋は，異形棒鋼を切削することにより作製した. 試験体一覧を表-6に示す．暴露後約1，2.5，3.8および5.7 年時に各 1 体ずつ試験に供した。 なお，一部，暴露前に 曲げ載荷によりひび割れを導入した。試験体側面から測 定した鉄筋位置におけるひび割れ幅（以下，かぶり位置 のひび割れ幅と呼ぶ）を表-6中に示した。これは暴露前 あるいは解体時にコンクリート表面で測定したものであ る. なお，解体時の方が $0.15 \sim 0.55 \mathrm{~mm}$ （比率とすれば約 2倍）程度大きくなっている.この原因の1つとして，本 試験体は護岸背後に設置されていたため, 暴露期間中に 何度か越波による衝撃を受けたことがあり，その際にひ び割れ幅が増加したことなどが考えられる，また，表中
表-6 小型角柱試験体一覧

1)ひび割れ無し:N

\begin{tabular}{|c|c|c|c|c|c|c|}
\hline \multirow{2}{*}{$\begin{array}{c}\text { 試験体 } \\
\text { 名称 }\end{array}$} & \multirow{2}{*}{ 鋼種 } & \multirow{2}{*}{$\begin{array}{c}\text { かぶり } \\
(\mathrm{mm})\end{array}$} & \multicolumn{4}{|c|}{ 腐食の有無（○:有, -:無） } \\
\hline & & & 1 年 & 2.5 年 & 3.8年 & 5.7 年 \\
\hline \multirow{2}{*}{$\mathrm{N}-\mathrm{N}$} & \multirow{2}{*}{$\mathrm{N}$} & 20 & 0 & 0 & 0 & 0 \\
\hline & & 43.5 & - & ○軽微 & 0 & 0 \\
\hline \multirow{2}{*}{$430-\mathrm{N}$} & \multirow{2}{*}{430} & 20 & 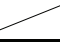 & - & - & - \\
\hline & & 43.5 & 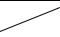 & - & - & - \\
\hline \multirow{2}{*}{$304-N$} & \multirow{2}{*}{304} & 20 & 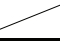 & - & - & - \\
\hline & & 43.5 & 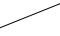 & - & - & - \\
\hline \multirow{2}{*}{$316-\mathrm{N}$} & \multirow{2}{*}{316} & 20 & - & - & - & - \\
\hline & & 43.5 & - & - & - & - \\
\hline
\end{tabular}

2)ひび割れあり : C

\begin{tabular}{|c|c|c|c|c|c|c|}
\hline \multirow{2}{*}{$\begin{array}{c}\text { 試験体 } \\
\text { 名称 }\end{array}$} & \multirow{2}{*}{ 鋼種 } & \multirow{2}{*}{$\begin{array}{c}\text { かぶり } \\
(\mathrm{mm})\end{array}$} & \multicolumn{4}{|c|}{ かぶり位置のひび割れ幅(mm) } \\
\hline & & & 1年 & 2.5年 & 3.8年 & 5.7年 \\
\hline \multirow{5}{*}{$\mathrm{N}-\mathrm{C}$} & \multirow{5}{*}{$\mathrm{N}$} & (0)* & 0.47 & 0.27 & 0.32 & 0.38 \\
\hline & & \multirow{2}{*}{20} & 0.20 & 0.20 & 0.25 & 0.20 \\
\hline & & & 0.40 & - & - & 0.35 \\
\hline & & \multirow{2}{*}{43.5} & 0.10 & 0.10 & 0.15 & 0.10 \\
\hline & & & 0.30 & - & - & 0.30 \\
\hline \multirow{5}{*}{$430-C$} & \multirow{5}{*}{430} & (0)* & 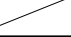 & 0.27 & 0.72 & 0.42 \\
\hline & & \multirow{2}{*}{20} & 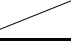 & 0.20 & 0.65 & 0.25 \\
\hline & & & 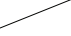 & - & - & 0.45 \\
\hline & & \multirow{2}{*}{43.5} & 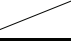 & 0.10 & 0.55 & 0.15 \\
\hline & & & $\gamma$ & - & - & 0.50 \\
\hline \multirow{5}{*}{$304-C$} & \multirow{5}{*}{304} & (0)* & 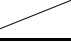 & 0.38 & 0.75 & 0.50 \\
\hline & & \multirow{2}{*}{20} & 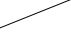 & 0.35 & 0.75 & 0.20 \\
\hline & & & $=$ & - & - & 0.50 \\
\hline & & \multirow{2}{*}{43.5} & 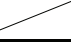 & 0.30 & 0.75 & 0.15 \\
\hline & & & & - & - & 0.50 \\
\hline \multirow{5}{*}{$316-\mathrm{C}$} & \multirow{5}{*}{316} & (0)* & 0.90 & 0.45 & 0.45 & 0.83 \\
\hline & & \multirow{2}{*}{20} & 0.35 & 0.35 & 0.35 & 0.25 \\
\hline & & & 0.70 & - & - & 0.80 \\
\hline & & \multirow{2}{*}{43.5} & 0.20 & 0.20 & 0.20 & 0.20 \\
\hline & & & 0.40 & - & - & 0.75 \\
\hline
\end{tabular}

上段: 暴露前の值, 下段: 解体時の值

$* 0 \mathrm{~mm}$ の值は推測值

-: ひび割れ幅未測定, 太字 : 腐食発生

には参考としてコンクリート表面のひび割れ幅の推測值 (図-5中の $w_{0}$ ) も示した（2種類ある場合は大きい方の み）.この $w_{0}$ は既知の2箇所のひび割れ幅（図-5中の $w_{20}$, $\left.w_{43.5}\right)$ から比例計算により求めた.

ii) はり試験体

試験体概略を図-6および表-7に，コンクリート配合を 表-5に示す. 使用したセメントは普通ポルトランドセメ

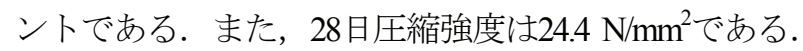
暴露後1.0，3.0および5.1年時に各 1 体ずつ試験に供した. 試験体寸法は $180 \times 300 \times 1750 \mathrm{~mm}$ であり，曲げ降伏が先 行する試験体とした（計6体）。主筋はD22，せん断補 強筋はD10である. 試験体に対して2点載荷を行い，ひ び割れを生じさせた，暴露前あるいは解体前に測定した かぶり位置の最大ひび割れ幅を表-7中に示した．載荷状 況は，主筋のみを降伏させた場合（表-7中：-S），主筋 
1,750

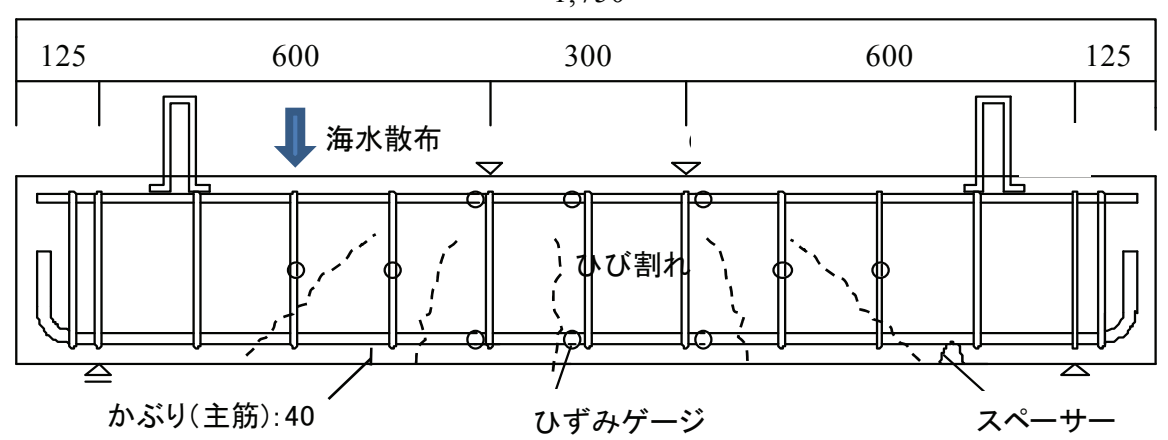

図一は試験体形状

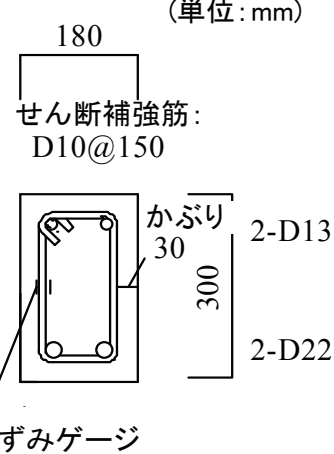

表-7 はり試験体一覧

\begin{tabular}{|c|c|c|c|c|c|c|}
\hline \multirow{2}{*}{$\begin{array}{c}\text { 試験体 } \\
\text { 名称 }\end{array}$} & \multirow{2}{*}{$\begin{array}{c}\text { 初期 } \mathrm{Cl} \text { 量 } \\
\left(\mathrm{kg} / \mathrm{m}^{3}\right)\end{array}$} & \multicolumn{2}{|c|}{ 事前の載荷状況 } & \multirow{2}{*}{$\begin{array}{c}\text { 最大 } \\
\text { ひび割れ } \\
\text { 幅(mm) } \\
\end{array}$} & \multirow{2}{*}{$\begin{array}{l}\text { 解体 } \\
\text { 時期 } \\
\text { (年) }\end{array}$} & \multirow{2}{*}{$\begin{array}{c}\text { 腐食の } \\
\text { 有無 }\end{array}$} \\
\hline & & 主筋 & $\begin{array}{l}\text { せん断 } \\
\text { 補強筋 }\end{array}$ & & & \\
\hline $304-S$ & 0 & 降伏 & 弾性 & 0.7 & 5.1 & 無 \\
\hline $304-\mathrm{L}$ & 0 & 降伏 & 降伏 & 2.0 & 3.0 & 無 \\
\hline $304-\mathrm{L}-\mathrm{Cl}$ & 3.0 & 降伏 & 降伏 & 2.0 & 1.0 & 無 \\
\hline $\mathrm{N}-\mathrm{S}$ & 0 & 降伏 & 弾性 & $1.5^{*}$ & 5.1 & 有 \\
\hline $\mathrm{N}-\mathrm{L}$ & 0 & 降伏 & 降伏 & $2.5^{*}$ & 3.0 & 有 \\
\hline $\mathrm{N}-\mathrm{L}-\mathrm{Cl}$ & 3.0 & 降伏 & 降伏 & 2.0 & 1.0 & 有 \\
\hline
\end{tabular}

およびせん断補強筋の両方を降伏させた場合(表-7中 : L)の2種類である。試験体304S，304-L，304-L-Clに対し てステンレス鉄筋（SUS304）を用い，試験体N-S，N-L, N-L-Clに対して普通鉄筋（SD295）を用いた。また，304 L-ClおよびN-L-Clについては，腐食環境をより厳しくす るため, 塩化物イオンをコンクリート中に $3.0 \mathrm{~kg} / \mathrm{m}^{3}$ 混入 した.

\section{b) 試験環境}

実際の海洋環境下と同様に，コンクリート外部から塩 化物イオンが浸透する場合を想定し，自然海水の散布が 1日2回（1回約3時間）繰り返される屋外環境（(独)港湾 空港技術研究所内の海水シャワー暴露場）に，小型角柱 試験体を5.7年，はり試験体を5.1年間暴露した。この際， 海水が散布される面（上側となる面）が，前者は図-5の 下側，後者は図一の上側となるように設置した。 なお， 海水シャワー暴露場の改良工事のために海水散布が停止 される期間が生じている（小型角柱試験体は100日間, はり試験体は292日間）。

\section{c) 試験項目}

\section{i) 小型角柱試験体}

試験体解体時に，コンクリート中の塩化物イオン濃度 および鉄筋腐食面積率を測定した。

塩化物イオン濃度の測定は，JCI-SC4に準拠し，電位 差滴定法により行った. 鉄筋位置の塩化物イオン濃度は, 図-5に示寸場所から試料を採取して測定した。また，材 齢1年時の夕，鉄筋を埋設していない試験体（150×150 ×150mm）を用いて，塩化物イオン濃度分布を測定した． 材齢3.8および5.7年時においては，ひび割れ近傍の物質 濃度分布を把握するために，EPMA(Electron prove micro analyzer)を実施した。測定対象とした元素のうち， $\mathrm{Ca}(\mathrm{CaO}), \mathrm{Cl}$ の2元素の結果を今回用いた（図-11参照）。 この際，鉄筋表面から $5 \mathrm{~mm}$ の範囲の測定值の平均值を採 用した。

鉄笳腐食面積率の測定は，腐食部分を透明フィルムに 写し取ることにより行った。 なお，鉄筋全長（356mm） に対して腐食面積を測定し，鉄筋全長の表面積で除すこ とにより求めた.

材齢5.7年時には，コンクリートの飽水率wを測定した。 試験体N-Cの表面から $20 \sim 40 \mathrm{~mm}$ 付近から試料を $30 \mathrm{~g}$ 程度 採取し, $w=0.93$ が得られた。

ii) はり試験体

塩化物イオン濃度の測定は，小型角柱試験体同様の方 法で実施した．鉄筋位置の塩化物イオン濃度は，図-5同 様にひび割れ近傍から試料を採取して測定した．濃度分 布ははり底面のひび割れなしの部分から試料を採取して 測定した.

材齗3および5.1年時においては，ひび割れ近傍の物質 濃度分布を把握するために EPMAを実施した。 小型角柱 試験体の場合と同様に，測定対象とした元素のうち $\mathrm{Ca}(\mathrm{CaO}), \mathrm{Cl}$ の元素の結果を今回用いた（図-15参照）。 この際，鉄筋表面から $5 \mathrm{~mm} の$ 範囲の測定值の平均值を採 用した。

腐食面積率の測定は，主鉄筋を $150 \mathrm{~mm}$ 程度に切断した 後，小型試験体同様の方法で行った（せん断補強筋では 未測定）。そのため，ここで得られる腐食面積率は各鉄 筋長（150mm程度）における腐食面積の割合となる.

\section{(2) 小型角柱試験体における試験結果 a) 腐食面積率}

図-7に腐食面積率の時間変化をひび割れあり，なしに 分けて示した. なお，腐食の有無については表-6中にも 示している、ひび割れ無しの場合，普通鉄筋の腐食はあ 

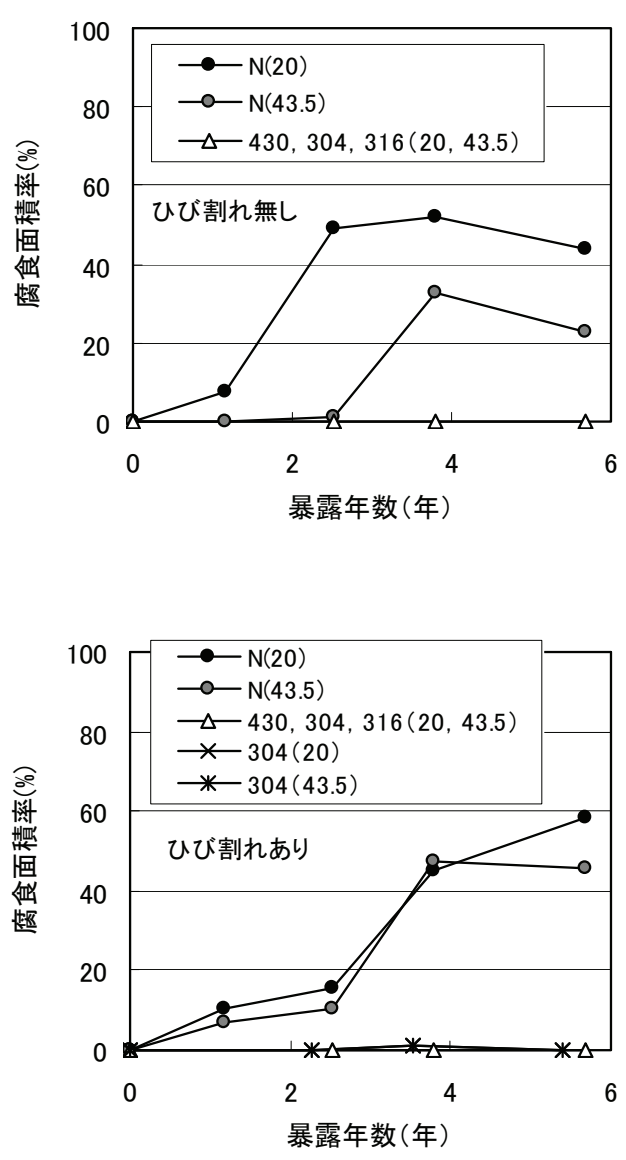

図-7 腐食面積率の変化

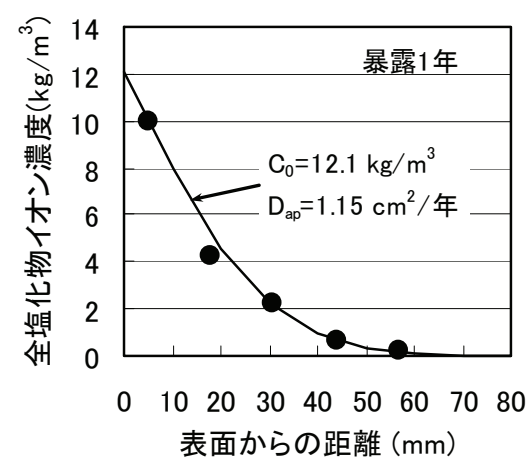

図-8 塩化物イオン濃度分布 (ひび割れなしの部分)

る段階から開始し，その後徐々に進行していることが分 かる．ステンレス鉄筋にはいずれも腐食が認められなか った.

ひび割れ有りの場合，普通鉄筋の腐食は，かぶりの違 いにかかわらず，暴露1年の時点で開始していることが 分かる．一方，SUS430とSUS316はいずれも腐食が観察 されなかった. SUS304については，暴露3.8年時にのみ， 海水が直接接触していたと推測されるひび割れ部で腐食 が観察された。 なお，腐食の形態は指で拭けば取れるよ うな液状のものであった．ステンレス鉄筋の含有成分上 における耐食性の順序SUS430 < SUS304 < SUS316と異な
り, SUS304のみで腐食が観察された理由についてはc)で 述べる.

b) 鉄筋位置における塩化物イオン濃度

暴露1年時に測定した，ひび割れのないコンクリート 部における塩化物イオン濃度分布を図-8に示す．多量の 塩化物イオンが外部から侵入している. Fickの拡散方程 式の解を用いて, 表面塩化物イオン濃度 $C_{0}$ を算出寸ると $12.1 \mathrm{~kg} / \mathrm{m}^{3}$ であった.

図-9は，各鉄筋位置の塩化物イオン濃度と腐食面積率 の関係を示す。なお，暴露3.8年時の結果は，塩化物イ オン濃度の測定值が存在しないため掲載していない，普 通鉄筋の場合, 塩化物イオン濃度が $2 \mathrm{~kg} / \mathrm{m}^{3}$ （=「港湾の

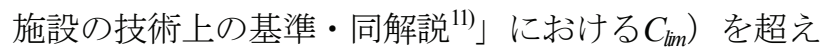
ると明確な腐食が見られた．各ステンレス鉄筋の場合， 高濃度となっても腐食が生じておらず， $C_{\text {lin }}$ が2 $\mathrm{kg} / \mathrm{m}^{3} よ$ りもかなり大きいことが分かる. 図-9中に各試験体にお いて測定された最大值を記入している. SUS430で14.5 $\mathrm{kg} / \mathrm{m}^{3}$, SUS304で $12.0 \mathrm{~kg} / \mathrm{m}^{3}, \quad$ SUS316で14.2 kg/m゙あった. 寸なわち, 腐食発生限界塩化物イオン濃度 $C_{\text {lin }}$ は少なく ともこれらの值以上であると言える. なお，3.の模擬溶 液浸漬試験結果や既往の知見2,3,12)等から推測すると，こ れらの值以上の值となる可能性が高く, その際のC $C_{\text {lin }}$ の 值の序列は，ステンレス鉄筋の含有成分上における耐食 性の順序と同様にSUS430＜SUS304＜SUS316となると考 えられる。

\section{c) ひび割れ近傍での腐食に関する考察}

図-10は，かぶり位置のひび割れ幅と腐食面積率の関 係を示す，なお，ひび割れ幅は暴露前と解体時の測定值 のうち大きい方を採用した。腐食が見られたSUS304

（暴露3.8年）の場合，ひび割れ幅が比較的大きく，暴 露前で $0.75 \mathrm{~mm}$ であった. ひび割れ幅が大きいことで, 海水が直接接触し，腐食が生じや寸い状況であったと考 えられる.また，この結果は，ステンレス鉄筋の耐食性 がSUS304やSUS430程度の場合, ある程度ひび割れ幅を 制御し，海水が直接接するのを防ぐ必要があることを示 唆するものである．写真-1は，腐食が見られたSUS304 と腐食が見られなかったSUS430におけるひび割れ面の 状況を示寸。腐食が見られていないSUS430のひび割れ 面は変色していないが，腐食が確認されたSUS304のひ び割れ面は全面にわたって茶色に変色している。これは, ひび割れの内部まで海水が直接供給され, 海水が鉄筋に 直接接していたことを意味している.

図-11は，暴露3.8および5.7年時において，ひび割れ近 傍の物質濃度分布をEPMAにより測定したものである. ひび割れ面が変色していた暴露3.8年のSUS304の場合, ひび割れ付近でCaの低下傾向が最も顕著である。これ はセメント水和物の溶出が多く生じていたことを示唆す るものである. 言い換えると海水と多く接触したことを 

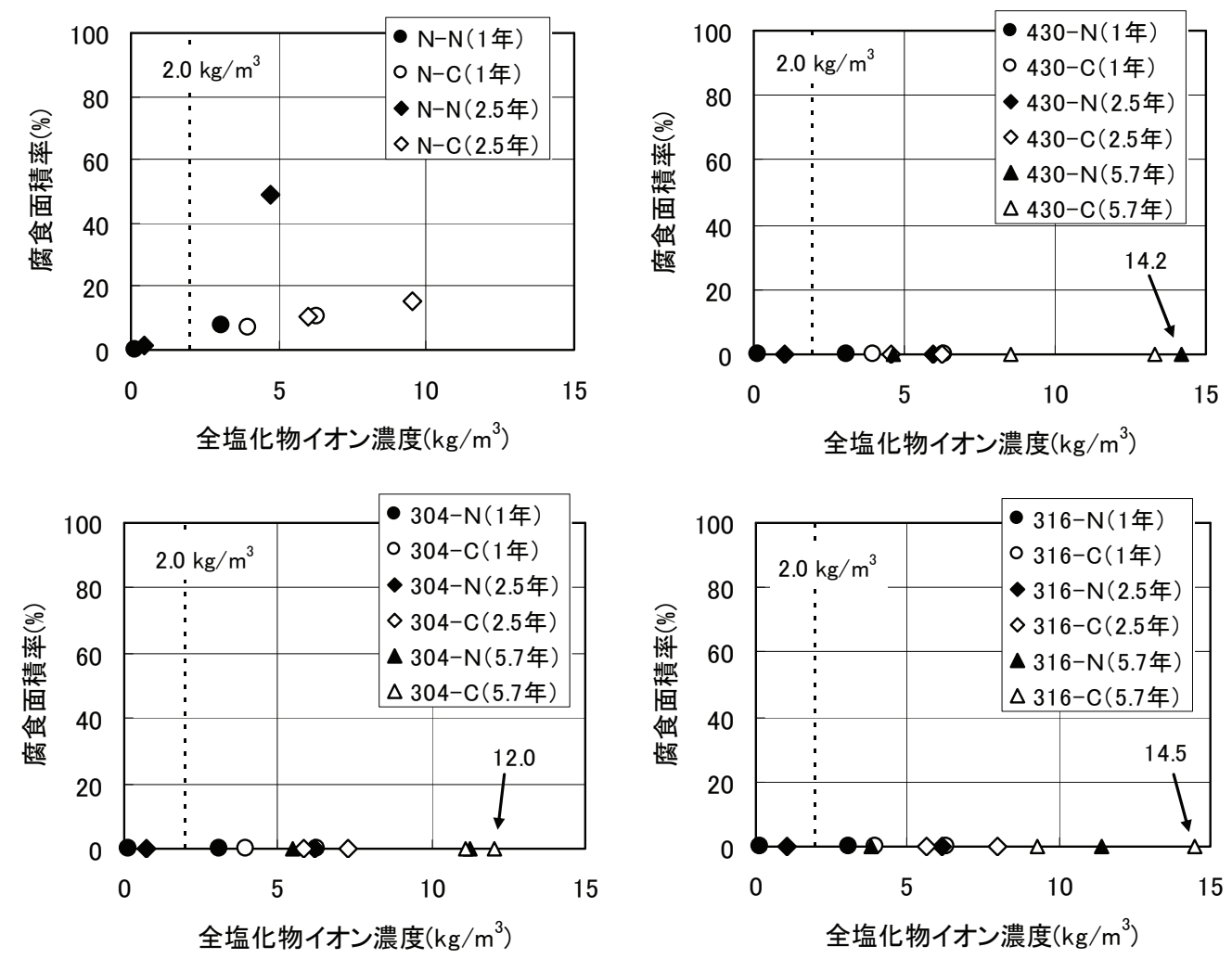

図-9 鉄筋位置の塩化物イオン濃度と腐食面積率の関係
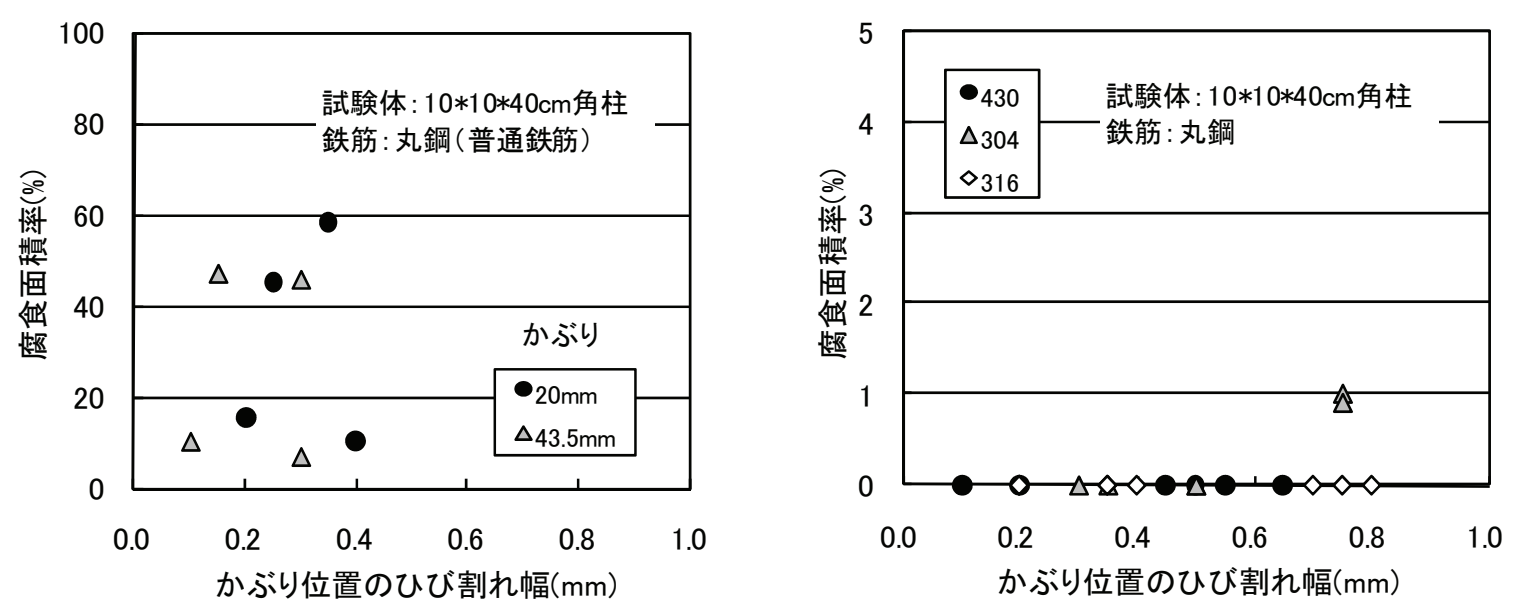

図-10 かぶり位置のひび割れ幅と腐食面積率の関係

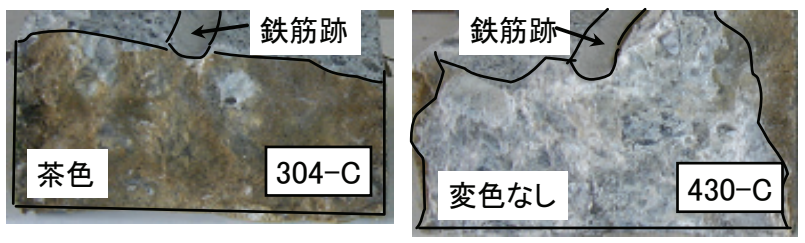

写真-1 ひび割れ面の変色状況（暴露 3.8 年）

意味する．また， $\mathrm{Cl}$ 濃度もひび割れ近傍で顕著に減少 している，ひび割れ面が変色していなかった暴露3.8年 のSUS430の場合にもCaおよびClの減少傾向は確認され たが，SUS304の場合に比べて緩やかであった. 一方，
暴露5.7年の場合，Clついてはいずれもひび割れ近傍 $10 \mathrm{~mm}$ 程度の範囲で減少傾向が見られたが，Caについて はいずれも顕著な溶出傾向は見られていなかった。この ように暴露3.8年時でCaの溶出傾向が顕著であった理由 

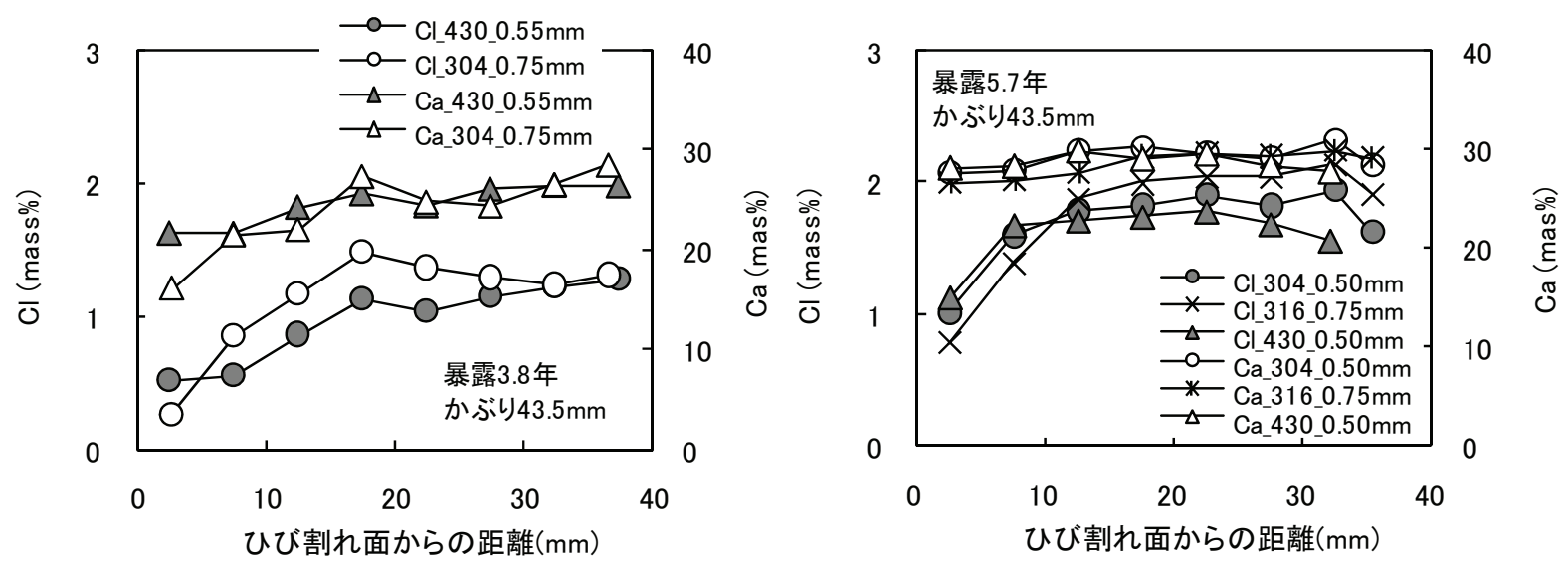

図-11 ひび割れ近傍の $\mathrm{Cl}$ おび $\mathrm{Ca}$ 濃度分布（暴露 3.8 およ゙ 5.7 年）

（凡例 : 元素-ステンレス鋼種-かぶり位置でのひび割れ幅）

は，実際のかぶり位置のひび割れ幅が，暴露5.7年の值 と比べて大きかったためと推測される.

以上より, 暴露3.8年時のSUS304で腐食が見られた理 由は, かぶり位置のひび割れ幅が大きく, 海水が直接接 していたためと考えられる。一方，SUS304より耐食性 に劣るSUS430で腐食が見られなかった理由は，かぶり におけるひび割れ幅が小さいなどの理由により，海水が 直接接していなかったためと考えられる. なお，暴露前 のかぶり位置20mmでのひび割れ幅でSUS304:0.75mm, SUS430 : 0.65mm, 43.5mmの位置でSUS304:0.75mm, SUS430 : 0.55mmと，SUS304とSUS430で0.1〜0.2mmしか 差がないが，前述したように，解体時のひび割れ幅はよ り大きな值であった可能性が高い. よって実際の差はよ り大きかったものと考える.

また，今回の結果は鉄筋が丸鋼の場合のものである. 丸鋼であるために，通常使用される異形鉄筋の場合と比 べて鉄筋とコンクリートの付着が十分でないことが，よ り腐食しやすい環境を作り出した可能性も考えられる. 異形鉄筋の場合の結果については，4.(3)で述べる.

一方，普通鉄筋の場合には，かぶりが20あるいは 43.5mm と非常に小さいこともあり，かぶり位置のひび 割れ幅が $0.1 \sim 0.2 \mathrm{~mm}$ 程度でも暴露後 1 年には腐食が生じ ていた．それに対してステンレス鉄筋の場合は，かぶり 位置のひび割れ幅が $0.5 \mathrm{~mm}$ 程度では腐食が確認されなか った.この結果は，ステンレス鉄筋における鋼材の腐食 に対するひび割れ幅の限界值 $w_{a}$ が，普通鉄筋の場合と比 べて大幅に緩和可能であることを示寸ものである.

\section{(3)はり試験体における試験結果}

\section{a) 腐食面積率}

図-12に主筋における腐食面積率の分布を示寸．なお， 位置 $0 \mathrm{~cm}$ は試験体の中心位置である。普通鉄筋の場合,

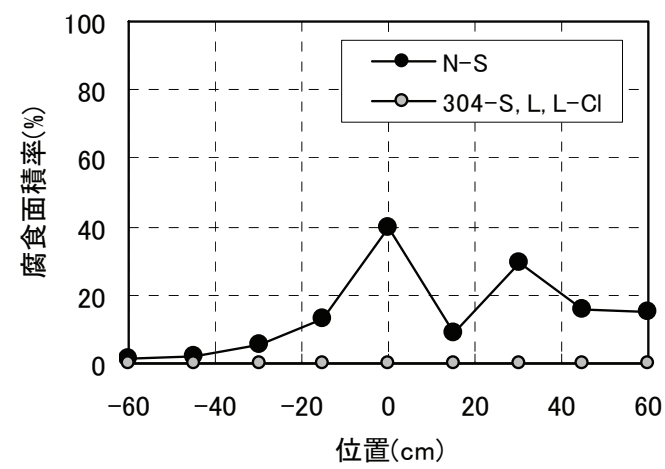

図-12＼cjkstart腐食面積率の分布（主筋）

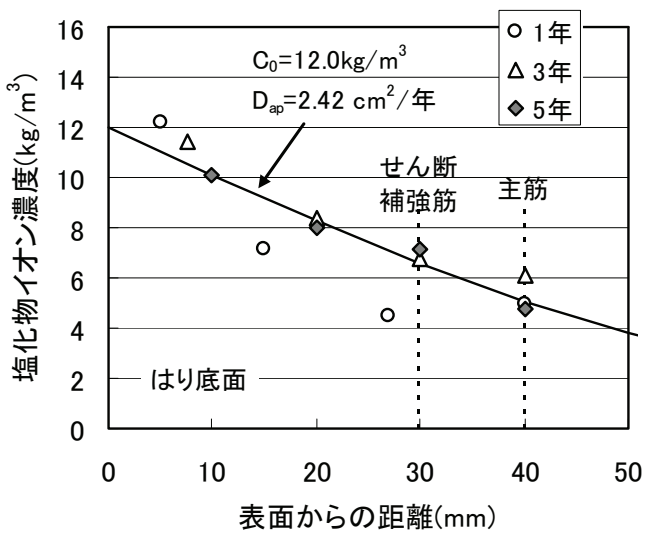

図-13 塩化物イオン濃度分布 (ひび割れなしの部分）

明確な腐食が観察されており，特にはり中心位置などひ び割れが存在している位置で腐食量が多くなっていた。 一方，ステンレス鉄筋（SUS304）の場合，どの試験体 においても目視により腐食は観察されなかった.

\section{b) 鉄筋位置における塩化物イオン濃度}

図-13はひび割れがないコンクリート部での塩化物イ オン濃度分布である．暴露5.1年時において，主筋位置 
では5 kg/m 程度, せん断補強筋位置では7 kg/m 程度の塩 化物イオンが浸透していた。 腐食は観察されていないた め, SUS304における限界塩化物イオン濃度 $C_{\text {lin }}$ はこれら の值以上であると言える.

図-14は，ひび割れ付近の鉄筋表面における塩化物イ オン濃度を，ひび割れ幅との関係で整理したものである. $10 \mathrm{~kg} / \mathrm{m}^{3}$ 程度の值を示すものが多く, 最大の濃度は 12 $\mathrm{kg} / \mathrm{m}^{3}$ 程度であった。しかし，どの鉄筋に腐食は見られ ていない。この結果から, 図-9同様に, SUS304の $C_{\text {lin }}$ は 少なくとも $12 \mathrm{~kg} / \mathrm{m}^{3}$ 程度以上であるといえる.

図-15はEPMAにより測定したひび割れ近傍のClおよび Ca濃度分布である.Clについてはかぶり位置でのひび割 れ幅が $0.70 \mathrm{~mm}$ の場合に顕著な減少が確認されたが，Ca については顕著な溶出傾向は見られなかった. よって, はり試験体の場合，小型角柱試験体の場合よりも，ひび 割れ近傍への海水供給量は少なかったものと推測される. この理由としては，4.(1)b)で述べたように，小型角柱試 験体とは海水が散布される面が異なり，はり試験体の場 合はひび割れ幅の大きい面（図-6の下側）に海水が直接 当たりにくかったことが考えられる.

\section{c) 鋼材の腐食に対するひび割れ幅の限界值に関する考察}

図-16はSUS304の場合の，かぶり位置のひび割れ幅と 腐食面積率の関係である。最大で2 $\mathrm{mm}$ 程度のひび割れ 幅の場合でも腐食が観察されなかった．前述のように， 海水が散布される面が異なるため，はり試験体の場合は 小型角柱試験体場合よりもひび割れ近傍の鉄筋表面に海 水が供給されにくい，そのため，腐食が生じていた小型 角柱試験体(SUS304，暴露3.8年)よりひび割れ幅が大きく ても腐食が観察されなかったものと考える. 仮にはり試 験体の底面側を上向きに設置していた場合や，試験体が 海中部あるいは干満帯に設置されていた場合は，鉄筋表 面に海水が直接供給されやすく,ひび割れ幅が大きい場 合においては腐食が開始・進行していたかもしれない.

「土木学会コンクリート標準示方書[設計編 $]^{13)}$ (以下, JSCE示方書）」では，鋼材の腐食に対するひび割れ幅 の限界值 $w_{a}$ (コンクリート表面における值) を以下の式 で求めてよいとしている.

一般環境の場合 : $w_{a}=0.005 c$

厳しい腐食環境の場合 : $w_{a}=0.004 c$

特に厳しい腐食環境の場合： $w_{a}=0.0035 c$

ここで，c:かぶりである. 図中に，はり試験体にお ける $c=40 \mathrm{~mm}$ の值を一般環境の場合の式に代入した $w_{a}$ の 值(0.20)を示した。今回のはり試験体の結果（SUS304製 の異形鉄筋）において，測定されたかぶり位置のひび割 れ幅が上述の $w_{a}=0.20 \mathrm{~mm}$ を大きく上回っているにもかか わらず，腐食は観察されなかった。 寸なわち，4.(2)c)で も述べているように，ステンレス鉄筋を使用する際は，
普通鉄筋の場合と比較して，鋼材の腐食に対するひび割 れ幅の限界值 $w_{a}$ を緩和できることが分かる．なお，一般 にwaはコンクリート表面における值であるが，今回測定 したひび割れ幅はかぶり位置における值である. かぶり

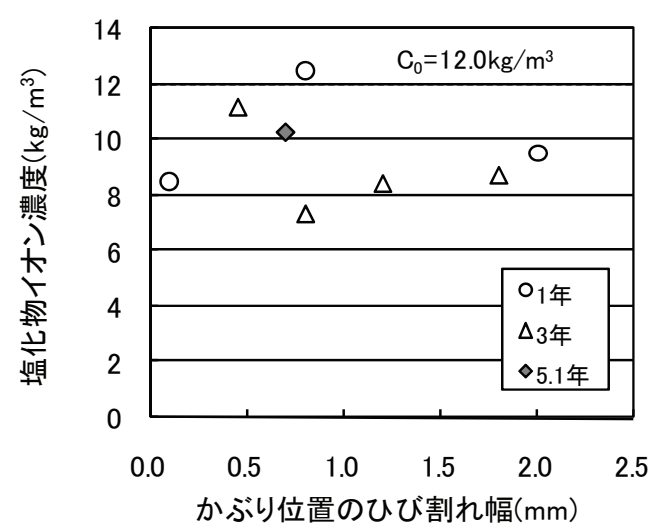

図-14 ひび割れ近傍の鉄筋位置における 塩化物イオン濃度

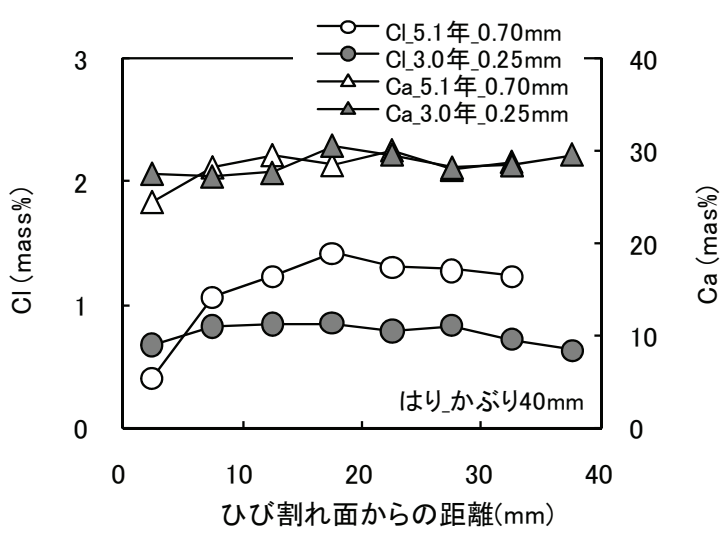

図-15 ひび割れ近傍の $\mathrm{Cl}$ および $\mathrm{Ca}$ 濃度分布 (暴露 3.0 および 5.1 年)

(凡例 : 元素-暴露期間-かぶり位置でのひび割れ幅)

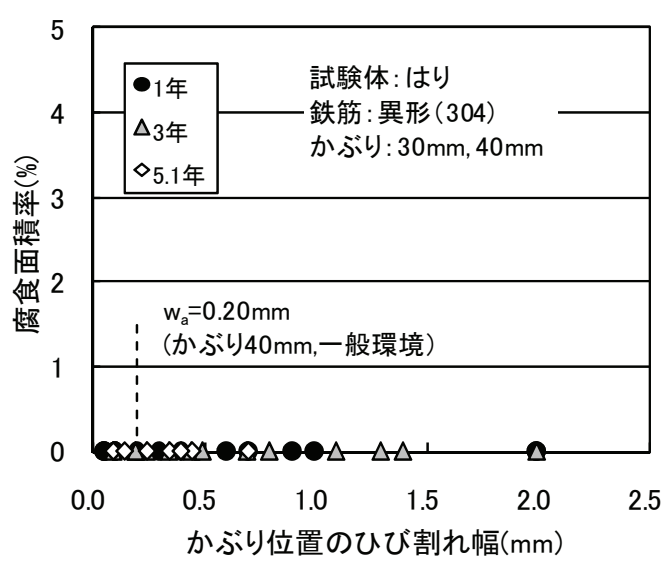

図-16 ひび割れ幅と腐食面積率の関係(SUS304) 
位置の方がコンクリート表面よりも值は小さくなるため, かぶり位置のひび割れ幅で整理している今回の結果は安 全側の評価となる.

\section{5. ステンレス鉄筋を用いた港湾RC構造物の初期建 設費用およびライフサイクルコストの試算例}

\section{(1) 概要}

港湾コンクリート構造物の中で最も厳しい塩害環境下 に位置している栈橋上部工について，「JSCE示方書」 の手法に基づき，鉄筋腐食に関する照査を行う．なお， 部分係数, $C_{0}, C_{\text {lin }}$, 塩化物イオン拡散係数については, 「港湾の施設の技術上の基準・同解説（以下，港湾基 準) ${ }^{111} 」 に$ 記載されている值を用いた。 そして初期建設 費用およびLCC（ライフサイクルコスト）計算を試みた。 なお，初期建設費用およびLCC計算方法については文献 14)を参考にした.

\section{(2) ステンレス鉄筋を用いた際の鉄筋腐食に関する照査}

設計対象の栈橋の断面を図-17に，鉄筋腐食に関する 照査の際の主要な条件一覧を表-9に示す．この際，鉄筋 位置における塩化物イオン濃度 $C_{d}$ の将来予測は, Fickの 拡散方程式の解である式(7)を用いて行う。

$$
C_{d}=\gamma_{c l} C_{0}\left(1-e r f\left(\frac{0.1 c}{2 \sqrt{D_{d} t}}\right)\right)
$$

ここで, $\gamma_{d l}$ : 鉄筋位置における塩化物イオン濃度の設計 用值 $C_{d}$ のばらつきを考慮した部分係数（一般に1.0）, $C_{0}$ : 表面塩化物イオン濃度 $\left(\mathrm{kg} / \mathrm{m}^{3}\right), c$ : かぶりの期待值

20.0

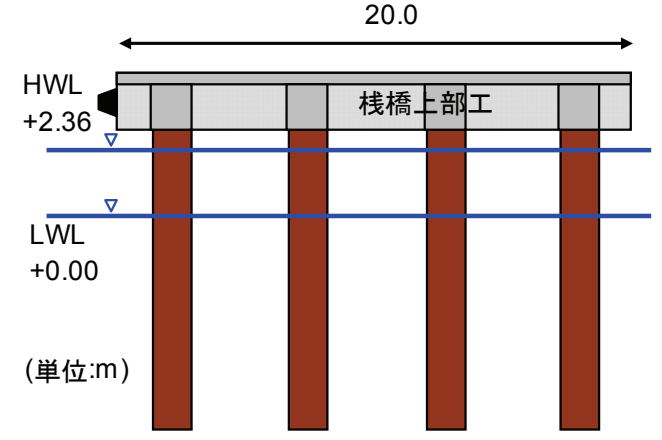

図-17 設計断面

表-9 計算条件

\begin{tabular}{|c|c|c|c|}
\hline \multirow{2}{*}{$\begin{array}{l}\text { 菜 } \\
\text { 甚 }\end{array}$} & セメント & $\mathrm{N}$ & BB \\
\hline & $\mathrm{W} / \mathrm{C}$ & \multicolumn{2}{|c|}{0.55} \\
\hline \multirow{4}{*}{$\begin{array}{l}\mathbb{x} \\
1 \\
x \\
1 \\
0\end{array}$} & $\mathrm{D}_{\mathrm{d}}\left(\mathrm{cm}^{2} /\right.$ 年 $)$ & 1.56 & 1.04 \\
\hline & $\mathrm{C}_{0}\left(\mathrm{~kg} / \mathrm{m}^{3}\right)$ & \multicolumn{2}{|c|}{15.1} \\
\hline & $\mathrm{c}(\mathrm{mm})$ & \multicolumn{2}{|c|}{50} \\
\hline & $\mathrm{t}$ (年) & \multicolumn{2}{|c|}{100} \\
\hline
\end{tabular}

$(\mathrm{mm}), D_{d}$ : 見かけの塩化物イオン拡散係数の設計值 $\left(\mathrm{cm}^{2} /\right.$ 年 $), t$ : 設計耐用年数, erf $(\mathrm{s}):$ 誤差関数, である.

今回の試算において，W/Cについては「港湾の施設の 技術上の基準・同解説」旧版 ${ }^{15}$ における上限值である 0.55 と設定した. 既設港湾構造物の大半の配合がこの值 に近いと推測される，かぶりcについては，「港湾基 準」における一般環境での最小值である $50 \mathrm{~mm}$ と設定し た. $C_{0}$ につては, 「港湾基準」における最大值である $15.1 \mathrm{~kg} / \mathrm{m}^{3}$ と設定した． $D_{d}$ については，「港湾基準」に示 されている以下の方法により求めた.

塩化物イオンに対する設計拡散係数 $D_{d}$ は, 式 (8) に より求められる.

$$
D_{d}=\gamma_{c} D_{k}+\left(\frac{w}{l}\right)\left(\frac{w}{w_{a}}\right)^{2} D_{0}
$$

ここで， $\gamma_{c}$ : コンクリートの材料係数（一般に1.0), $D_{k}$ : コンクリートの塩化物イオンに対する拡散係数の特 性值 $\left(\mathrm{cm}^{2} /\right.$ 年, 式(9)), $D_{0}$ : コンクリート中の塩化物イオ ンの移動に及ぼすひび割れの影響を表す定数（一般に $200 \mathrm{~cm}^{2} /$ 年) $, w:$ ひび割れ幅 $(\mathrm{mm}), w_{a}$ : ひび割れ幅 の限界值 $(\mathrm{mm}), w / l$ : ひび割れ幅とひび割れ間隔の比, である.

コンクリートの塩化物イオンに対する拡散係数の特性 值 $D_{k}$ は，式(9)を用いて定めることができる.

$$
D_{k}=\gamma_{p} \alpha D_{p}
$$

普通ポルトランドセメントを使用する場合

$$
\log D_{p}=-3.9(W / C)^{2}+7.2(W / C)-2.5
$$

高炉セメントやシリカフュームを使用する場合

$$
\log D_{p}=-3.0(W / C)^{2}+5.4(W / C)-2.2
$$

ここで， $\alpha$ : 換算係数（普通ポルトランドセメントの場 合：一般に 0.65 , 高炉セメントやシリカフュームを使用 寸る場合：一般に1.0)， $\gamma_{p}: D_{p}$ の精度に関寸る安全係数 (一般に1.0)， $D_{p}$ : コンクリートの拡散係数の予測值 ( $\mathrm{cm}^{2} /$ 年) , である.

設計拡散係数 $D_{d}$ 算出の際は，セメントを普通ポルトラ

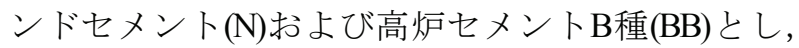
$W / C=0.55$ とした．また，ひび割れに関するパラメータは， 文献14）を参考に $w / l=0.00158, w_{d} / w=1.0$ とした. これらの 值を代入して算出した $D_{d}$ を表-9中に示した.

これらの值を式(7)に代入して100年後における塩化物 イオン濃度分布を予測した結果を図-18に示寸．かぶり が50 mmの場合, 鉄筋位置の塩化物イオン濃度は $12 \mathrm{~kg} / \mathrm{m}^{3}$ 程度まで増加した。一方，4.で実施された海洋環境暴露 実験の結果において, どのステンレス鉄筋も $12 \mathrm{~kg} / \mathrm{m}^{3}$ で は腐食は発生していなかった. すなわち, 今回使用した 


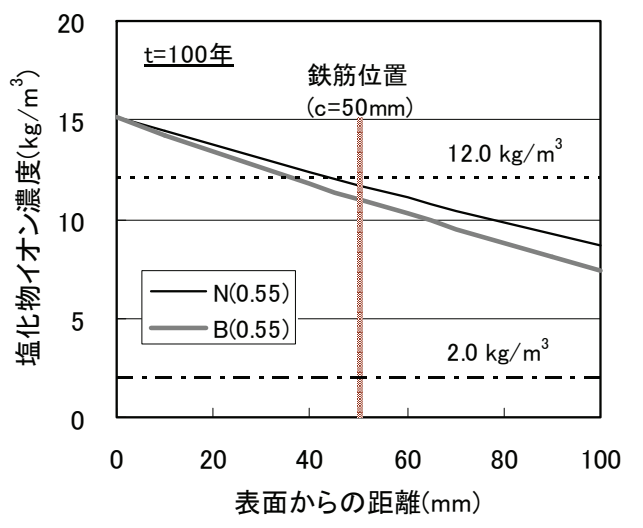

図-18 100 年後の塩化物イオン濃度分布

ステンレス鉄筋であれば，計算上は100年間腐食しない こととなる．すなわち，供用期間中において，コンクリ 一ト構造物に対する補修は不要となる.

一方，普通鉄筋の場合において，腐食発生限界塩化物 イオン濃度 $C_{\lim }$ を $2.0 \mathrm{~kg} / \mathrm{m}^{3}$ と設定し，この条件以外は表-9 の計算条件として鉄筋腐食が開始する時期 $\left(C_{d}=C_{\lim }\right.$ と なる時期）を計算すると，セメントがN $(W / C=0.55)$ で かぶり $50 \mathrm{~mm}$ の場合は3.5年，セメントがBB（W/C=0.55） でかぶり 50mmの場合は5.3年で腐食が開始する結果とな る.

\section{(3) 初期建設費用およびライフサイクルコストの試算}

初期建設費用およびLCCを試算する際において，ステ ンレス鉄筋の種類は特に定めず，材料単価が普通鉄筋と 比べて5倍, 10倍の場合について計算を行った.

文献14）において，図-17の設計断面に対して，普通 鉄筋をかぶり $70 \mathrm{~mm}$, コンクリートの水セメント比 $W / C=0.45$ （セメントは普通ポルトランドセメント）とし た場合における上部工の初期建設費用の試算が行われて いる. この試算結果を基にしてステンレス鉄筋の場合の 初期建設費用およびLCCの試算を行う。ステンレス鉄筋 の場合については，文献14）の試算結果において，かぶ りやW/C は普通鉄筋の場合と同じとして, 鉄筋の単価の みを変化させることにより算出した. なお，5.(2)の試算 条件（表-9） と比べてかぶりは大きく，W/Cは小さい. よって，ステンレス鉄筋の性能を考慮して初期コストを 算出すると文献14)の結果よりも安くなる．厳密にはこ れらも考慮すべきだが，今回は概算の比較が主目的であ るため，ステンレス鉄笳にとっては安全側の評価（より 高価な評価）である文献14)の結果をそのまま引用する こととした．また，ステンレス鉄筋の使用によりひび割 れ幅の限界值 $w_{a}$ が緩和されることを考慮すると初期コス トはさらに安くなるが，ここでは考慮していない. 初期建設費用の試算結果の例を図-19に示す。なお,

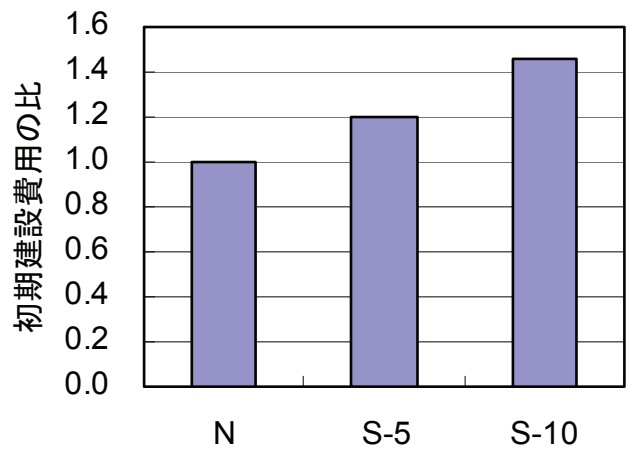

図-19 初期建設費用の比

普通鉄筋の場合の費用を 1.0 として，それに対する比で 示している.ここで，Nは普通鉄筋，S-5は単価が普通鉄 筋の5倍，S-10は10倍を意味している。初期建設費用はS5で普通鉄筋の約1.2倍，S-10で約1.4倍となった。

LCCの計算結果は仮定条件によって大きく異なる. こ こでは，文献14)におけるLCC試算結果の一部を，5.(2)の 計算手法に基づき，再計算したものを参考にして比較を 行う。図-20は，図-19での普通鉄筋における初期建設費 用を基にLCCの時間変化を試算した例である，なお，普

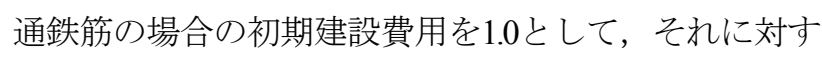
る比で示している. ここで，B-1は供用前にコンクリー 卜表面に塗料などによる被覆を行い，随時塗り替えを行 った場合，B-2は供用前には何も行わず，劣化が進行し 始めた時期に鉄筋に電気防食を行った場合である. 計算 条件に一覧を表-10にまとめた。詳細については，文献 14)に示されているので概略のみを以下説明する.

i)B-1の場合

供用前にコンクリート表面に被覆を行っているため, 鉄筋腐食に関する照査は行っていない，ただし，表面を 被覆した材料が10年で劣化すると想定し，10年ごとに塗 り替えを行うとした.

ii)B-2の場合

塩化物イオンがコンクリート中に侵入し，鉄筋腐食が 開始・進行すると, 腐食による膨張圧でコンクリートに 鉄筋腐食ひび割れが生じる。この時点で，電気防食によ る補修を実施することとした，なお，腐食ひび割れが発 生する腐食量および鉄筋の腐食速度の值は，文献16の 值を参考に設定した（表-10中に掲載）.

ステンレス鉄筋を用いた場合（S-5，S-10），初期建設 費用は普通鉄筋を用いた場合に比べて高い.しかし，普 通鉄筋の場合，B-1の試算結果が示すように，初期に被 覆を行った時点でほぼ同等の費用がかかり，1回でも塗 り替えを行うとステンレス鉄筋を用いた場合より高くな る. 一方，電気防食(B-2)による補修を実施する場合，1 回でも対策を実施するとその時点でステンレス鉄筋の初 


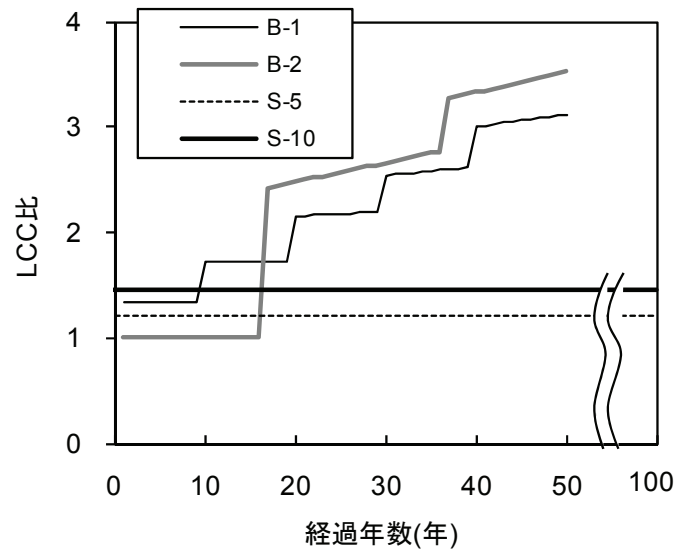

図-20 LCC 比の時間変化

表-10 劣化予測における計算条件

\begin{tabular}{|c|c|c|c|}
\hline$B-1$ & \multicolumn{3}{|c|}{ 条件: 初期から被覆. 10年ごとに塗替 ${ }^{14)}$} \\
\hline \multirow{12}{*}{ B-2 } & \multicolumn{3}{|c|}{ 条件: 腐食ひび割れ発生後に電気防食 ${ }^{14)}$} \\
\hline & パラメータ & 設定値 & 参考文献·式 \\
\hline & $D_{d}$ & 0.9 & 文献11), 14) \\
\hline & $\mathrm{C}_{0}$ & 14.3 & 文献11), 14） \\
\hline & $\mathrm{C}_{\lim }$ & 2.0 & 文献11) \\
\hline & $\mathrm{c}(\mathrm{mm})$ & 70 & 文献14） \\
\hline & 鉄筋腐食開始時期(年) & 12.6 & 式(7) \\
\hline & $\phi(\mathrm{mm})$ & 29 & 文献14） \\
\hline & $\begin{array}{l}\text { 腐食ひび割れが発生す } \\
\text { 腐食量 }\left(\mathrm{mg} / \mathrm{cm}^{2}\right)\end{array}$ & 24.1 & 文献16） \\
\hline & 腐食速度 $\left(\mathrm{mg} / \mathrm{cm}^{2} /\right.$ 年 $)$ & 6.0 & 文献16） \\
\hline & $\begin{array}{l}\text { 腐食開始〜腐食ひび割 } \\
\text { れまでの期間(年) }\end{array}$ & 4.0 & \\
\hline & $\begin{array}{l}\text { 腐食ひび割れ発生時期 } \\
\text { (年) }\end{array}$ & 16.6 & \\
\hline
\end{tabular}

期建設費用より大幅に高くなる，すなわち，ステンレス 鉄筋（S-5，S-10）を使用した場合，栈橋上部工の初期建 設費用は普通鉄筋の場合よりも1〜1.5倍程度高くなるが, 供用期間中に各種補修が必要となるような厳しい環境下 においては，LCCで比較すると安くなる場合があること が分かる.

なお，初期建設費用LCC試算結果は，構造物の条件， 環境条件など各種条件によって大きく変化するため，こ こで示した試算結果はある一例にしか過ぎないことを明 記しておく

\section{6. まとめ}

海洋環境下におけるコンクリート中のステンレス鉄筋 SUS304，SUS316，SUS430の耐食性，すなわち腐食発生 限界塩化物イオン濃度 $C_{\text {lin }}$ およひ鋼材の腐食に対するひ び割れ幅の限界值 $w_{a}$ にいて検討するため，ステンレス 鉄筋を埋設したコンクリート試験体（小型角柱試験体お よびはり試験体）を，自然海水が1日2回散布される環境
下（海洋環境下）に長期間暴露し，各種試験を実施した。 この際，腐食に及ぼすひび割れの影響を確認するため, 一部の試験体には暴露前にひび割れを導入した，得られ た知見を以下に示す.

(1) コンクリート中における $C_{\text {lin }}$ は普通鉄筋（炭素鋼）の 場合よりかなり大きな值を示すことが確認された.

SUS430の場合で $14.2 \mathrm{~kg} / \mathrm{m}^{3}$ 以上, SUS304の場合で 12.0 $\mathrm{kg} / \mathrm{m}^{3}$ 以上，SUS316の場合で $14.5 \mathrm{~kg} / \mathrm{m}^{3}$ 以上であると考え られた。 なお，これらの值は今回実験で測定された塩化 物イオン濃度の最大值であり, 各ステンレス鉄筋の $C_{\text {lin }}$ はこれらの值よりも大きくなる可能性が高い. その際, $C_{\text {lin }}$ の值の序列はステンレス鉄筋の含有成分上における 耐食性の順序と同様にSUS430 < SUS304 < SUS316となる と考えられる.

(2) 小型角柱試験体の結果において，ステンレス鉄筋 SUS430，SUS304およびSUS316を使用した場合，今回実 験におけるかぶり20あるいは43.5mmの範囲では，かぶ り位置のひび割れ幅が $0.5 \mathrm{~mm}$ 程度であっても，腐食が確 認されなかった，一方，普通鉄筋の場合は，今回実験に おけるかぶり20あるいは43.5mmの範囲では，かぶり位 置のひび割れ幅が $0.1 〜 0.2 \mathrm{~mm}$ 程度で腐食が発生していた. はり試験体の結果においては, 鉄筋（異形）がSUS304 の場合，今回実験におけるかぶり $30 \mathrm{~mm} の$ 範囲では，か ぶり位置のひび割れ幅が最大で $2 \mathrm{~mm}$ 程度の場合でも腐 食が観察されなかった．以上の結果は，ステンレス鉄筋 SUS430，SUS304およびSUS316を使用した場合，普通鉄 筋の場合と比較して，鋼材の腐食に対寸るひび割れ幅の 限界值 $w_{a}$ を大幅に緩和できることを示寸ものである．な お，一般にwaはコンクリート表面における值であるが， 今回測定したひび割れ幅はかぶり位置における值である. かぶり位置の方がコンクリート表面よりも值は小さくな るため, かぶり位置のひび割れ幅で整理している今回の 結果は安全側の評価となる.

そして最後に, 海洋環境暴露試験で得られた結果から, ステンレス鉄筋の $C_{\text {lin }}$ を仮定し，海洋環境に位置する栈 橋上部工におけるライフサイクルコストの試算を行った. その結果得られた知見を以下に示寸.

(3)ステンレス鉄筋を用いて建設した場合，供用期間中 のライフサイクルコストで比較すれば，普通鉄筋を用い て建設し，供用期間中に補修を行う場合より安くなる可 能性が示された.

謝辞 : 山梨大学高橋良輔氏（元港湾空港技術研究所）, 東京電力（株）平崎敏史氏（元港湾空港技術研究所特別 研究員），（株）ピーエス三菱青山敏幸氏（元港湾空港 技術研究所依頼研修生）には実験の実施に当たりご協力 を頂いた．大同特殊鋼（株）山川正克氏には試験体製作 時にご尽力頂いた。 ここに厚くお礼申し上げる. 


\section{参考文献}

1) The Concrete Society: Guidance on the use of stainless steel reinforcement, Technical report No.51, 1998.

2) Pedeferri, P., Bertolini, L., Bolzoni, F. and Pastore, T. : Behavior of stainless steel in concrete, Repair and rehabilitation of reinforced concrete structures: The state of art, American Society of Civil Engineers, 1998.

3) 太星鎬, 野口貴文, 兼松学, 宇城工 : 塩化物イオン を含んだコンクリート中の各種 $\mathrm{Cr}$ 鋼防食鉄筋の腐食 抵抗性に関する研究，コンクリート工学年次論文集, Vol.25, No.1, pp.803-808, 2003.

4) 山路徹, 水間誠治, 平崎敏史, 演田秀則 : 海洋環境 下におけるステンレス鉄筋の耐食性に関する検討, コンクリート工学年次論文集, Vol.27, No.1, pp.937942, 2005.

5) 山路徹, 青山敏幸, 山川正克, 清水哲也：コンクリ 一ト中におけるステンレス鉄筋の腐食性状，コンク リート構造物の補修, 補強, アップグレード論文報 告集, Vol.1, pp.69-74, 2001.10.

6) 例えば, 山本俊彦, 山路徹, 水間誠治 : ステンレス 鉄筋コンクリート部材の塩分耐食性実験, セメント・ コンクリート論文集, No.62, pp.311-317，2009.2.

7) ステンレス協会編：ステンレス鋼便覧, 日刊工業新 聞社, p.1362, 1994.

8) 望月紀保：コンクリート中の鉄筋の腐食・防食評価 技術に関する研究，秋田大学博士論文，1998.
9) 佃有射, 加藤碩, 丸屋剛, 山路徹 : ステンレス鋼材 の腐食発生限界塩化物イオン濃度に関する実験的検 討, コンクリート工学年次論文集, Vol.30, No.1, pp.1119-1124, 2008.

10) 石田哲也, 宮原茂禎, 丸屋剛：ポルトランドセメン トおよび混和材を使用したモルタルの塩素固定化特 性，土木学会論文集 E, Vol.63，No.1，pp.14-26， 2007.1.

11）（社）日本港湾協会：港湾の施設の技術上の基準 同解説（下），pp.486-491， 2007.

12) 田所裕, 佃有射, 山路徹, 丸屋剛, 二羽淳一郎：ス テンレス鉄筋のコンクリート中における腐食発生塩 化物イオン濃度に関する実験的研究, 土木学会論文 集 E, Vol.65, No.4, pp.522-529, 2009.11.

13) 土木学会 : コンクリート標準示方書[設計編 : 本編], pp.113-114, 2007.

14) 土木学会：土木学会コンクリート標準示方書に基づ く設計計算例[栈橋上部工編], コンクリートライブラ リー116, pp.81-115, 2005.

15) 日本港湾協会 : 港湾の施設の技術上の基準・同解説, p.336, 1999.

16)（財）沿岸技術研究センター：港湾の施設の維持管 理技術マニュアル，pp.201-208，2007.10.

(2009.11. 16 受付)

\section{STUDY ON THE CORROSION RESISTANT PROPERTY OF STAINLESS STEEL BARS UNDER MARINE ENVIRONMENT}

\section{Toru YAMAJI, Hidenori HAMADA, Seiji MIZUMA and Toshihiko YAMAMOTO}

For the durability enhancement of port RC structures, corrosion resistant property of three types of stainless steel bars (SUS430, SUS304 and SUS316) in concrete was studied by the exposure tests under marine environment. Results obtained are as follows. i) Each chloride threshold level for corrosion of these stainless steels was estimated higher than $12 \mathrm{~kg} / \mathrm{m}^{3}$ at least. ii) The upper limit of crack width for corrosion in case of these stainless steel bars can be increased than that in case of carbon steel bar. iii) In case that stainless steel bar is applied to port RC structures, the life cycle cost can be lower than the case of carbon steel bar. 